\title{
An Ecological Exploration of the Culture of English as an International Language Among Iranian English Language Teachers in Light of Vygotsky's Genotypic Approach
}

\author{
Majid Elahi Shirvan \\ University of Bojnord, Bojnord, Iran
}

\author{
Tahereh Taherian \\ Ferdowsi University of Mashhad, Mashhad, Iran
}

\begin{abstract}
Language ecology is defined as the study of the interactions between any given language and its environment. It is primarily determined by the people who learn it, who use it, and more important than the previous ones by the people who transmit it to the others; that is, language teachers. English language is used as an additional language almost all over the world and an indispensable part of the ecology of this international language is culture. Thus, an ecological perspective demands a particular view of the practice of the culture of English language as situated and localized. Exploring such practice within the diverse contexts of the use of English language should be based on the genesis underpinning English language teachers' thoughts and practice. Therefore, the purpose of the present study was to explore Iranian English language teachers' attitudes, knowledge, and skills of teaching culture in light of Vygotsky's genotypic approach. To do so, semi-structured interviews were conducted with 35 English language teachers in Iran. Their records were analyzed and discussed in terms of four different and interrelated spans, namely phylogenetic, cultural-historic, ontogenetic, and microgenetic. Phylogenetic span focuses on the development of language teachers as natural species and their physical evolution. The cultural historic span concerns the development of language teachers based on social, cultural, and historic bases. Ontogenetic domain investigates the role of language teachers across their human life span. Microgenetic span is related to a set of roles, activities, and interpersonal relations experienced by the developing person in a given setting. The findings of the study have indicated that there is a sharp contrast between Iranian English language teachers' attitudes towards teaching culture and their practice in the classroom which is due to the divergence between the their ontogenetic development of culture teaching on one hand and the policies of the English language institutes develop within the cultural historic span on the other hand.
\end{abstract}

Keywords: English as an additional language, language ecology, ontogeny, microgeny

\section{Introduction}

Haugen (1972) defines language ecology as the investigation of interactions between any given language and its environment. The true environment of a language is the society that uses it. Language ecology has two parts: (1) Psychological: its interaction with other languages in terms of bi- and multilingual speakers and (2) Sociological: its interaction with the society for the purpose of communication (Haugen, 1972). Thus, the 
ecology of a language is primarily determined by the people who learn it, who use it, and more important than the previous ones by the people who transmit it to the others; that is, language teachers.

In an ecological exploration, the context of education can be considered as a set of ecosystems, each one nested inside the next (Bronfenbrenner, 1979, 1993). Each system has a set of actors and artifacts, and also patterns of operations and relations. According to Bronfenbrenner (1993), there are four hierarchical ecosystems: micro-, meso-, exo-, and macrosystem, which are explained as follows:

The microsystem exists as the innermost layer, and is defined as "a pattern of activities, roles, and interpersonal relations experienced by the developing person in a given face-to-face setting" (Bronfenbrenner, 1993, p. 15), such as language classroom that individual and contextual factors interact to produce development. The mesosystem comprises the linkages between two or more settings leading to the developing person. The exosystem involves the relation between two or more settings, "at least one of which does not contain the person but in which events occur that indirectly influence process within the immediate setting" (Bronfenbrenner, 1993, p. 24). The macrosystem encompasses the overarching patterns of the characteristics (e.g., belief systems, life styles, or social structures) underlying the previous systems.

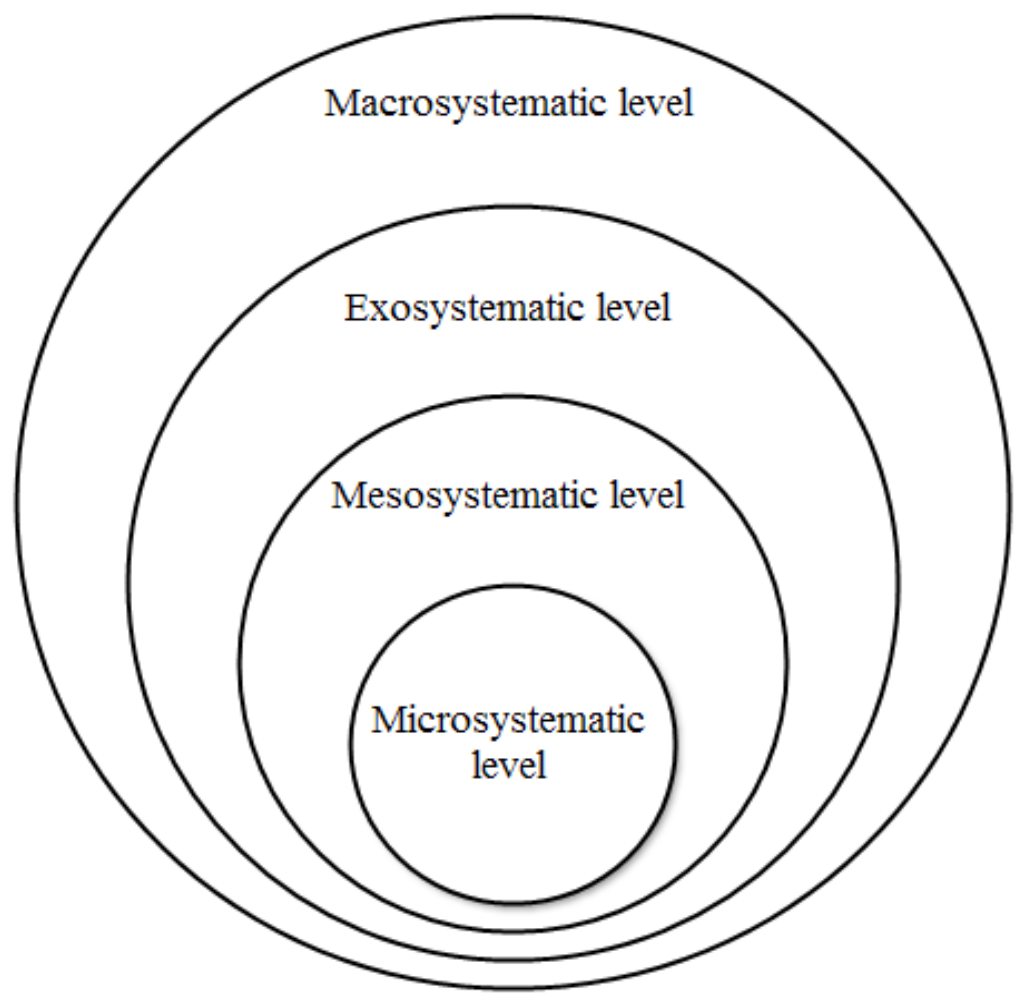

Figure 1. Hierarchical level of ecosystems (Bronfenbrenner, 1993).

Figure 1 shows the conceptualization of the ecosystems, and examples of their elements specified to the present study. The application of Bronfenbrenner's ecosystems model in second language research has been promising. Van Lier (2004) accentuated the usefulness of this model and applied it to examining the interdependent forces influencing the use of computer technology in language classes. 
Table 1

The Conceptualization of the Ecosystems and Their Examples

\begin{tabular}{|c|c|}
\hline Level & onceptualization \\
\hline$n$ & $\begin{array}{l}\text { L classroom within which culture of teaching Studying teachers' attitudes, knowledge, and skills of ICC; } \\
\text { glish as an additional Language was under institute environment; methods to teach ICC; tasks for } \\
\text { idy }\end{array}$ \\
\hline Mes & $\begin{array}{l}\text { The interconnection between the classroom and Teachers' past experiences and activities outside the } \\
\text { other settings containing the institute, academic classroom that shape culture of teaching English as an } \\
\text { context, teacher training course } \\
\text { additional Language }\end{array}$ \\
\hline Exc & $\begin{array}{l}\text { The interconnection between the universities and Curriculum design and the role of ICC in it; course } \\
\text { other institutes, which influences culture of assessment; observation checklist of institute for checking } \\
\text { teaching English as an additional Language teachers proficiency }\end{array}$ \\
\hline Macr & 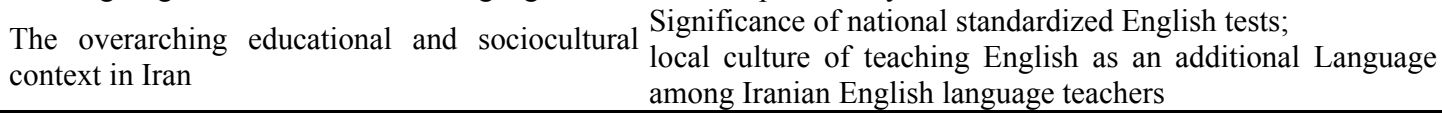 \\
\hline
\end{tabular}

The Bronfenbrenner's model focuses mainly on the relationships among ecosystems not on the nested set of systems. These "linkages" allow the researcher to instigate the forces between one ecosystem and another (Van Leir, 2004). With the spread of English language around the world and its current state as an international language, the ecology of English language has been expanded and an indispensible part of this ecology covers the role of culture. Indeed, with the increasingly multilingual and multicultural nature of global exchanges through the English language, the traditionally monolingual and monocultural nature of language education is now in question (Zarate, Lévy, \& Kramsch, 2008). In most foreign language textbooks, the typical communicative interactions include two or three interlocutors who all conduct the interaction in the same standard language, who all concur on what the aim of interaction is and what organizes a culturally proper topic of conversation, and who all have equal speaking rights and opportunities. But the reality is entirely different. Today, language users have to communicate in much less predictable way in which the interlocutors use a language and dialects for various identification purposes that are mostly rooted in the cultural background of those interlocutors (Kramsch, 2008). Thus, an ecological exploration stresses the social and historical dimension of English language teaching and the need not just to teach one culture but to put cultures in relation with one another (Kramsch, 2008).

As a result, an ecological investigation of the cultural and intercultural awareness of Iranian English language teachers and their ability of putting their knowledge into practice in the class needs to be conducted in light of the micro-macrosystems of language teaching ecosystem and the potential gap that might exist between the theoretical aspects of this awareness and practical aspects.

\section{Culture and Intercultural Competence}

An ecological perspective demands a particular view of the practice of the culture of English language as situated and localized. Byram (1989) defines culture as knowledge which is "shared and negotiated between people" and "much of that knowledge is symbolically expressed in artefacts and behaviours and is formulated as rules, norms, expectations, as moral and legal codes, as proverbs, as parental injunctions to children" (p. 82). Fang (2011) has described different paradigms of culture including "static" and "dynamic" paradigms (pp. 27-31). The assumptions of "static paradigm" include (Xu, 2013):

(1) The complex nature of culture is identified through simplification;

(2) Cultural differences are seen basically as a problem;

(3) Cultures can be investigated in bipolar cultural dimensions in which each culture has fixed characteristics; 
(4) The most crucial component of culture is value;

(5) The conception of culture is stable over time.

Fang (2011) states that the static paradigm is essentially a "pre-globalization and pre-Internet phenomenon" (pp. 28-29), thus it is unable of covering the dynamic nature of culture in a globalizing society or dealing with intra-cultural diversity. However, the "dynamic paradigm" of culture focused on intercultural interaction, "negotiated culture", and "multiple cultural identity" (Fang, 2011, p. 29). In the dynamic paradigm, cultural differences are seen essentially not as a problem but as an opportunity for learning and knowledge transfer, in which cultures are "negotiated, compromised, embraced, and transferred" (Fang, 2011, p. 30).

Kramsch (1993) has stated that the native culture of learners has an effect on how they learn about the target language and culture. Indeed, students do not shape new identity when they learn a new language but they form boundaries between the native culture and the target culture. Thus, a "third place" develops. In this process, learners decenter from their native culture, notice and perceive the target culture, and construct a third place where they can observe and reflect on both their own and the target culture (Byram, 1989; Kramsch, 1993). Kramsch has stated that in this third place, learners synthesize elements of different cultures and form their own conceptualization of the cultural differences between those cultures. It is an unbounded and dynamic space where language learners bridge the gap between cultural differences for the purpose of communication (Crozet \& Liddicoat, 2000).

In an ecological view of language, cultural diversity maximizes chances of human success and adaptability. One way of being able to adapt effectively and appropriately to diversity, whether ethnic, racial, religious, or cultural is by means of intercultural communicative competence (ICC). Fantini has defined ICC as the "ability to deal with differences in a positive manner" (2009, p. 25), and it entails "an individual's ability to communicate and interact across cultural boundaries" (Byram, 1997, p. 7). ICC has been defined in multiple ways, but in this research, it was understood not as an ability but as the overall social and psychological capacity of an individual to manage appropriately encounters with people from other cultural backgrounds (Byram, Gribkova, \& Starkey, 2002; Corbett, 2003; Bennett, 2004; Holliday, 2010; Deardorff, 2008).

Therefore, several models of intercultural competence have been developed to pinpoint the key elements of the concept. Two main models of ICC are as follows:

Bennett's developmental model of intercultural sensitivity. One of the classic models of intercultural competence is Bennett's Developmental Model of Intercultural Sensitivity (DMIS) developed in 1986 and 1993. This model was used to observe how students experience the process of adaptation to a new culture. Basically, the model clarified some stages that individuals went through to become adapted to new culture. Bennett calls them denial, defense, minimization, acceptance, adaptation, and integration- (Bennett, 2004, p. 63). These stages are divided into ethnocentric behaviors and ethnorelative behaviors, where individuals relativize the self and value the other.

Bennett's model has had a major effect on studying abroad courses and theories of culture shock. Yet, it was not designed for foreign language context. Hu and Byram (2009) have criticized the model in that it does not explain the role of language in the development of cultural sensitivity.

Byram's model of intercultural communicative competence. The best known model of intercultural competence is supplied by Byram (1997). Most definitions of intercultural competence are based upon this model today. As Byram (1997) has stated this model is designed to aid teachers of languages to realize the concept of intercultural competence. In his first step, he tried to clarify some factors that influence intercultural 
communication, namely attitudes, knowledge, and skills.

According to Byram, attitudes include a positive attitude to interact with others curiously and openly; in this way people can learn to value others and relativize self (Byram, 1997). The second factor is their knowledge. Byram divides this knowledge into two categories. The first is the "knowledge about social groups and their cultures in one's own country, and similar knowledge of the interlocutor's country" (Byram, 1997, p. 35). The second is procedural knowledge defined as "knowledge of the processes of interaction at individual and societal levels" (Byram, 1997, p. 36). This knowledge covers both linguistic and cultural elements of the language in intercultural communication. Finally, Byram identifies two skills that influence the success of intercultural communication which are dependent on the learners' knowledge and attitudes. Firstly, there are skills of interpreting and relating understood as "the ability to interpret a document or event from another culture, to explain it and relate it to documents from one's own" (Byram, 1997, p. 66). Secondly, it is discovering and interacting defined as the "ability to acquire new knowledge of a culture and cultural practices and the ability to operate knowledge, attitudes, and skills under the constraints of real-time communication and interaction" (Byram, 1997, p. 73).

Concluding from these factors, Byram associates intercultural competence with communicative competence, and thus introduces a model of intercultural communicative competence in language teaching. In this model, Byram describes intercultural competence in terms of a number of savoirs. He defines the first savoir as "knowledge of social groups and their products and practices in one's own and in one's interlocutor's country, and of the general processes of societal and individual interaction" (Byram, 1997, p. 58). Savoir-comprendre is defined as "the ability to interpret a document or event from another culture, to explain it and relate it to documents or events from one's own" (Byram, 1997, p. 61). Savoir-apprendre/faire is the "skill of discovery and interaction: ability to acquire new knowledge of a culture and cultural practices and the ability to operate knowledge, attitudes and skills under the constraints of real-time communication and interaction" (Byram, 1997, p. 61). Savoirs' engager is described as "critical cultural awareness/political education: an ability to evaluate, critically and on the basis of explicit criteria, perspectives, practices and products in one's own and other cultures and countries" (Byram, 1997, p. 63). Finally, savoir-être is defined as "curiosity and openness, readiness to suspend disbelief about other cultures and belief about one's own" (Byram, 1997, p. 57).

It deserves pointing out here that many of the facets of intercultural competence identified in the literature regarding intercultural training are implied in Byram's definition. However, Byram's intercultural competences are concerned with a general intercultural communicator. But, Kalsbeek ${ }^{1}$ (2008) has maintained that additional competences are needed for foreign language teachers: Not only should they be interculturally competent themselves, but also they should have the ability to convey these intercultural competences to their students. These additional competences are clarified in Kalsbeek's model (2006, p. 91) as "perspective", "context", and "dialogue".

Kalsbeek (2008) states that the term "dialogue" should be seen in the sense of constructing a third place as proposed by Kramsch (1993). As mentioned earlier, third culture is created by the communication between different cultural interlocutors, when both take some distance from their native culture, focus on the target culture, and construct a third place where they can observe and reflect on both their own and the target culture

\footnotetext{
1 Related to a project "Pilot for Developing a Course in Intercultural Competence for Foreign Language Teachers", a co-production of the Steunpunt Nederlands als vreemde taal of the University of Amsterdam (Alice van Kalsbeek) and the University College of London (Gerdi Quist) in 2008.
} 
(Byram, 1989; Kramsch, 1993).

Kalsbeek (2003) defines "competence as an adequately integrated implementing (general) knowledge and skills in a professional context" (p. 3). He makes a difference between the "general competences" for the interculturally competent individual and "profession oriented competences" for the foreign language teacher. He defines profession oriented competence as the ability to teach the intercultural communicative competence and to make students as "cultural beings" (Kalsbeek, 2008, p. 3). He states that all competences pivot on skills, knowledge, and attitude. General competences include openness, knowledge, and flexibility. Profession-oriented competences include perspective, context, and dialogues (see Table 2).

Table 2

Classification of General vs. Profession Oriented Competences

\begin{tabular}{llll}
\hline Competencies & Attitude & Knowledge & Skills \\
\hline General & Openness & Knowledge & Flexibility \\
Profession-oriented & Perspective & Context & Dialogue \\
\hline
\end{tabular}

As mentioned earlier, ecological exploration tries to explore language within its individuals, social, cultural, and historical frame work (Kramsch \& Steffensen, 2008). Exploring the ecology of English language with its diverse contexts can be conducted with regard to the genesis underpinning English language teachers' thoughts and practice; that is, Vygotsky's genotypic approach.

The idea of "history of behavior" or "genetic analysis" is the key principle of the "sociocultural theory" (Vygotksy, 1980). Genetic analysis involves four levels of analysis, namely phylogenetic, cultural-historic, ontogenetic, and microgenetic level (Vygotksy, 1980). Phylogenetic span focuses on the development of language teachers as natural species and their physical evolution. The cultural-historic span concerns the development of language teachers based on social, cultural, and historic bases. Ontogenetic domain investigates the role of language teachers across their human life span. Microgenetic span is related a set of roles, activities, and interpersonal relations experienced by the developing person in a given setting. Therefore, this study ecologically explores English language teachers' attitudes, knowledge, and skills of teaching culture in light of Vygotsky's genotypic approach.

\section{Method}

\section{Participants}

In order to examine English language teachers' attitudes, knowledge, and skills of teaching culture, a semi-structural interview with 35 English language teachers in Iran were conducted. Participants were interviewed individually and these sessions were audio-taped with their consent. These English language teachers were from five institutes of Mashhad, Iran; 22 were female and 13 were male. Their age ranged from 27 to 45 . Their teaching experiences ranged from 3 to 14 years. 17 had B.A.; 12 had master's degree; and 6 were Ph.D. candidates.

\section{Instrument}

Teachers' beliefs were profiled by means of an interview. Main guide for formulating the interview was Kalsbeek's (2008). The interview portfolio contained seven sections. The items addressed various facets of teachers' knowledge, skills, and attitudes with regard to "general competences" and "profession oriented competences" of the foreign language teacher. General competences included openness, knowledge, and 
flexibility. Profession-oriented competences included perspective, context, and dialogues. The average time needed to conduct the interview was about 15 minute.

The questions in the first section inquired about the respondents' sex, age, number of years of teaching experience, native tongue, and nationality. The questions in the second section, i.e., openness, concerned with the ability of teachers to develop an interest and gain an insight in other cultures. Section three addressed knowledge of teachers of the various ideas on culture and intercultural communication and the ability to transmit this knowledge to their students. Section four was related to the flexibility of teachers' behavior in various situations and the ability to guide their students to do so. The fifth section regarded teachers' perspective and the ability to think and act from different perspective and the ability to apply the term perspective in their teaching practice. The questions in section six investigated the knowledge of teachers of the target culture to add context to learning tasks and to the ability to instruct students searching for context. And finally the seventh section was associated with dialogues, the ability to understand the basics and problems of intercultural communication and to implement this knowledge in teaching practice. It should be mentioned that every section had two parts with regard to general competences and profession oriented competences.

\section{Data Analysis}

Each interview was transcribed and coded based on the different sections of the interview guide. Then, quantitative procedures were used to analyze the content of the interviews.

\section{Results}

\section{Openness}

Table 3 shows the result concerning the first section of the interview, i.e., openness towards other people and cultures. Interview questions one to eight were designed to find out the ability to develop an interest and gain an insight in other cultures of interviewees.

Table 3

Participant' Responses Regarding Openness

\begin{tabular}{|c|c|c|c|c|c|}
\hline Frequency & B.A. & M.A. & Ph.D. & Sum & Percentage \\
\hline $\begin{array}{l}\text { 1. I have a positive attitude toward the target culture and an } \\
\text { open mind towards other cultures. }\end{array}$ & 4 & 5 & 6 & 15 & 42 \\
\hline $\begin{array}{l}\text { 2. I am aware of my role as an intermediary between two } \\
\text { cultures. }\end{array}$ & 10 & 9 & 6 & 25 & 71 \\
\hline $\begin{array}{l}\text { 3. I am able to put the norms, values, and traditions of my } \\
\text { own culture into perspective. }\end{array}$ & 2 & 3 & 5 & 10 & 28 \\
\hline $\begin{array}{l}\text { 4. I can recognize stereotypical judgments on other cultures } \\
\text { and put them into perspective. }\end{array}$ & 1 & 2 & 4 & 10 & 20 \\
\hline $\begin{array}{l}\text { 5. I am able to see people from other cultures as } \\
\text { individuals, not only as representatives of their culture. }\end{array}$ & 1 & 3 & 4 & 8 & 22 \\
\hline 6. I can make students aware of their own cultural baggage. & 2 & 2 & 6 & 10 & 28 \\
\hline $\begin{array}{l}\text { 7. I can stimulate students to have an open mind when } \\
\text { regarding other cultures, and in particular when regarding } \\
\text { the target culture (values and beliefs). }\end{array}$ & 3 & 4 & 5 & 9 & 34 \\
\hline 8. I can teach students to be critical towards stereotypes. & 2 & 2 & 4 & 8 & 22 \\
\hline
\end{tabular}

Findings of the interviews regarding the theoretical aspects of openness. The results of the first interview questions revealed that about half of the teachers emphasized that they had positive attitude towards the target culture and they were open-minded toward other cultures. Majority of the interviewees (about $70 \%$ ) 
emphasized that they were aware of their role as an intermediary between two cultures. For instance, some teachers claimed that they provided some cultural content for the class. However, most of the participants concerned about the limitation of the time allocated for teaching culture in the classroom. About $20 \%$ of participants stated that they were able to recognize stereotypical judgments on other cultures. One of interviewees, a Ph.D. candidate, referred to this fact that Iranian learners of English had been influenced by other cultures and they accepted stereotypical judgments of these cultures without any critical thinking. He added that he tried to be aware of these serotypes and conveyed this awareness to his students.

As forth ability to put the norms, values, and traditions of their own culture into perspective, about $30 \%$ of participants stated that they could represent their own cultural value in the class. These teachers asserted that it was important for learners to be able to develop the competence to talk about their own culture and cultural identity. One of the instructors (M.A. student) stated that:

Typically, people involved in communication want to express who they are and what kind of cultural background they represent, and as a result, an emphasis on learner's culture should be taken into account in English classes in order to have a better communication. (personal communication)

About $20 \%$ of the teachers asserted that they were able to see people from other cultures as individuals, not only as representatives of their culture. But, most of the interviewees believed that the culture of the environment influenced the people of that context so they could not see people separated from their culture as an individual.

Findings of the interview regarding the practical aspects of openness. $30 \%$ of participants contended that they were able to make students aware of their own cultural baggage. However, most of the teachers mentioned to some limitations for teaching other cultures. For instances, one teacher, who was M.A. student, alleged that:

There is no appreciation of teaching culture in the policies of the institute I work at. Similarly, there is no point for teaching culture in the observation checklists in the institutes. Consequently, despite the importance of promoting the culture and intercultural awareness of the learners, the time, tests, and the regulations of the class limit me to allocate adequate time to this part. (personal communication)

$40 \%$ of the interviewees claimed that they could stimulate their students to have an open mind regarding other cultures. For example, one of interviewees (a B.A. teacher) maintained that he tried to arouse curiosity and attention of the learners towards the target culture by using self-prepared materials. This participant elaborated this as follows:

It is important to force students to fully understand the American culture. I try to use music, movie, food, literature, poetry, and photographs of people who are important in the target culture, and fully involve learners in the culture not simply the language. In this way, I can arouse my students' awareness to be open minded with regard to that culture. (personal communication)

The point is that this teacher insisted on the American culture all the time. It is inferred that the materials she used definitely included examples mainly from the target language culture and other cultures were neglected completely.

$20 \%$ of the teachers reported that they were able to teach students to be critical towards stereotypes. For example, one of the teachers (a Ph.D. candidate) mentioned that for developing students' critical thinking towards stereotypes, he compared the Iranian culture with other cultures. In her own words, she commented that: 
In order to promote my students' critical thinking towards stereotypes, I usually use Iranian culture as the starting point, because they normally have background about it. Then, my students and I compare our culture with the target culture. After that, we talk about things that would be stereotypical in both cultures.

However this interviewee alleged supervisors in the many institutes acknowledged linguistic competence of teachers rather than their cultural and intercultural awareness.

\section{Knowledge}

Interview items 9 to 15 aimed to find out the interviewees' knowledge of various ideas on culture and intercultural communication and whether they could transmit these to their students or not (see Table 4).

Table 4

Participants' Responses Regarding Knowledge

\begin{tabular}{|c|c|c|c|c|c|}
\hline Frequency & B.A. & M.A. & Ph.D. & Sum & Percentage \\
\hline 9. I know that culture can be defined in different ways. & 7 & 9 & 6 & 22 & 62 \\
\hline $\begin{array}{l}\text { 10. I have knowledge of the different ideas on the } \\
\text { relationship between language and culture. }\end{array}$ & 4 & 8 & 6 & 18 & 51 \\
\hline $\begin{array}{l}\text { 11. I have knowledge of different models of intercultural } \\
\text { communication. }\end{array}$ & 2 & 4 & 5 & 11 & 31 \\
\hline $\begin{array}{l}\text { 12. I know the different interpretations of "multi-cultural", } \\
\text { "cross-cultural", and "trans-cultural". }\end{array}$ & 0 & 1 & 3 & 4 & 11 \\
\hline $\begin{array}{l}\text { 13. I am able to integrate my knowledge of culture and } \\
\text { intercultural communication into my practice as a teacher. }\end{array}$ & 1 & 1 & 3 & 5 & 14 \\
\hline $\begin{array}{l}\text { 14. I can give students an insight into the various ideas on } \\
\text { culture and intercultural communication. }\end{array}$ & 2 & 3 & 5 & 10 & 28 \\
\hline $\begin{array}{l}\text { 15. I pay attention in my teaching practice to the ways in } \\
\text { which "multi-cultural", "cross-cultural", "trans-cultural", } \\
\text { and "intercultural" play a role in the target culture. }\end{array}$ & 0 & 1 & 2 & 3 & 8 \\
\hline
\end{tabular}

Findings of the interviews regarding the theoretical aspects of knowledge. Regarding item nine, i.e., the definition of culture and different ways of defining culture, about $60 \%$ of interviewees claimed that they knew what culture was and also they could explain culture in different ways. The majority of the teachers emphasized the importance of shared norms, values, behavior and an identity in defining culture.

In the next interview item, item 10, the teachers were asked to explain about different ideas on the connection between language and culture; the results of interview revealed that half of the participants knew the relationship between language and culture and they gave various ideas about this connection. A Ph.D. candidate response is as follows:

In my opinion, language is just a part of culture, a shared language, allowing people of different cultures to express themselves and communicate in a way so that everyone understands in the same way what they are talking about. And, so the culture is maintained through communication either in speech or in written form. Unfortunately, despite the importance of culture for developing communication competence of students, supervisors of the English language institutes mainly credit their teachers with their linguistic competence rather than their intercultural competence. (personal communication)

Regarding item 11, interviewees were asked whether they had any knowledge of different models of intercultural communication. About $30 \%$ of the participants were aware of the different models of intercultural communication.

Item 12 investigated interviewees' interpretation of the three concepts of "multi-cultural", "cross-cultural", and "trans-cultural". About $10 \%$ of teachers could explain the differences between these three terms. 
Findings of the interview regarding the practical aspects of knowledge. In item 13, teachers were asked whether they could integrate their knowledge of culture and intercultural communication into their practice as a teacher. $10 \%$ of the teachers claimed that they could integrate intercultural communication with their class activity. For instances, one participant stated that he promoted cultural and intercultural communication of learners by using speaking activities, using visual materials, hands-on materials, teaching about various cultures, and arousing curiosity towards other cultures. However, the majority of participants did not find the current textbooks they used in the classroom sufficient in order to promote intercultural competence of their learners. In addition, some interviewees stated that text books and policies of English language institutes had too much emphasis on grammar and too much focus on the British or American culture, thus, lack of adequate information about various cultures to provide learners with.

Item 14 addressed the ability of the teachers to give students an insight into the various ideas on culture and intercultural communication. About $30 \%$ of participants claimed that they had this ability. One interviewee (a Ph.D. candidate), for instance, contended that:

In order to give my students a perspective towards different ideas on culture, I ask them to find some friends from foreign countries, pen-pals, or I organize some competitions requiring cultural knowledge. Additionally, I ask them to prepare some posters or involve in different projects related to different cultures. (personal communication)

\section{Flexibility}

The two items in this section aimed to investigate teachers' ability to adopt appropriate behavior in various situations and guide their students to do so (see Table 5).

Table 5

Participants' Responses Regarding Flexibility

\begin{tabular}{llllll}
\hline \multicolumn{1}{c}{ Frequency } & B.A. & M.A. & Ph.D. & Sum & Percentage \\
\hline Questions & 5 & 4 & 5 & 14 & 40 \\
16. I am curious about new cultures. & 1 & 1 & 2 & 4 & 10 \\
17. I can guide students on their international mobility. & 1 & & \\
\hline
\end{tabular}

Findings of the interviews regarding the theoretical aspects of flexibility. Regarding the item $16,40 \%$ of participants stated that they were curious about new cultures. One of the B.A. teachers, for instance, mentioned that:

I am curious about new cultures. In my opinion, acquisition of new cultures gives me a wider perspective. In addition, globalization, and travelling are other reasons for the importance of learning about new cultures. (personal communication)

Findings of the interview regarding the practical aspects of flexibility. Item 17 addressed the ability of teachers in guiding students on their international mobility. $10 \%$ of the interviewees claimed that they had this ability; a Ph.D. candidate explained that he tried to prepare students for their international mobility by giving them social and sociolinguistic skills. However, most interviewees stated that time limitation did not allow them in orienting their students to their international mobility.

\section{Perspective}

Section five, six, and seven belonged to the profession-oriented competences and consisted of perspective, context, and dialogues. Interview items 18 to 22 tried to find out the ability of teachers to think and 
act from different perspectives and to apply the term "perspective" in their teaching practice. Results are shown in Table 6.

Table 6

Participants' Responses Regarding Perspective

\begin{tabular}{|c|c|c|c|c|c|}
\hline Frequency & B.A. & M.A. & Ph.D. & Sum & Percentage \\
\hline $\begin{array}{l}\text { 18. I can recognize the perspective from which a text is } \\
\text { spoken or written. }\end{array}$ & 3 & 2 & 4 & 9 & 25 \\
\hline $\begin{array}{l}\text { 19. I am able to take the others perspective during } \\
\text { intercultural communication. }\end{array}$ & 0 & 0 & 2 & 2 & 5 \\
\hline $\begin{array}{l}\text { 20. I am aware of the ethnocentric view of many classroom } \\
\text { practices. }\end{array}$ & 0 & 1 & 3 & 4 & 11 \\
\hline $\begin{array}{l}\text { 21. I can make students aware of the cultural notions that } \\
\text { are hidden in their actions and thoughts. }\end{array}$ & 0 & 1 & 2 & 3 & 8 \\
\hline $\begin{array}{l}\text { 22. I can teach students to analyze and recognize the } \\
\text { various perspectives from which texts are produced in a } \\
\text { foreign language. }\end{array}$ & 2 & 2 & 3 & 7 & 20 \\
\hline
\end{tabular}

Findings of the interviews regarding the theoretical aspects of perspective. With respect to item 18 , the interviewees were asked whether they could identify the underlying perspective in spoken or written texts. About $25 \%$ of the teachers claimed that they had this ability. A Ph.D. candidate pointed out that:

Texts are shaped and influenced by some ideological, historical, and political purposes. In order to identify the perspective of a text, I try to look back upon the history of English, getting familiar with the political English context, and questioning some of the assumptions in a text. (personal communication)

Item 19 considered the perspective towards others during intercultural communication. That is, whether teachers can communicate with others without stereotypical views and whether they can understand the complexity of whom they are. As the results showed, just 5\% of the interviewees had this ability. Most of the participants stated that they responded to people according to what they have heard about them rather than according to how they find them.

Findings of the interviews regarding the practical aspects of perspective. The results of item 20 revealed that approximately $10 \%$ of the teachers were aware of the ethnocentric view of many classroom practices. Most of the teachers asserted that they did not care about different ethnic groups in the class.

Item 21 investigated one aspect of applying the term perspective in teaching practice, i.e., the ability to make students aware of the cultural notions hidden in their actions and thoughts. As shown in the Table 5, about $10 \%$ of the teachers took advantage of this awareness. For instance, one of the Ph.D. candidates stated that:

I try to incorporate my students' daily activities to enable them to think critically about their cultural notions and explore possibilities for change if needed. For example, I try to raise my students' awareness of the stereotypically gender-oriented views towards education. (personal communication)

With regard to item 22, the participants were asked whether they could teach my students to analyze and recognize the various perspectives from which texts were produced in a foreign language. $20 \%$ of the interviewees reported that they could do this. One of the B.A. teachers asserted that:

Well, unfortunately English language institutes rarely appreciate paying attention to introducing different perspectives from which a text is produced. Additionally, there is no point for assessing the ability to analyze and recognize various perspectives in texts in teachers' observation checklists. As a result, it is not accepted for learners to take time in this part. 
Consequently, if I did not follow this rule, I would lose my face and popularity among students because what matters to them is the language not the culture. (personal communication)

\section{Context}

Table 7 shows the results in regard to the context of other people and cultures. Interview questions 23 to 28 were designed to find out the knowledge of teachers of the target culture to add context to learning tasks and to instruct students searching for context.

Table 7

Participants' Responses Regarding Context

\begin{tabular}{|c|c|c|c|c|c|}
\hline Frequency & B.A. & M.A. & Ph.D. & Sum & Percentage \\
\hline $\begin{array}{l}\text { 23. I have a general knowledge of the geography, history, } \\
\text { society, and government of the target culture. }\end{array}$ & 3 & 2 & 5 & 10 & 28 \\
\hline $\begin{array}{l}\text { 24. I stay updated on political, artistic, literary, fashion, and } \\
\text { architectonic developments in the target culture. }\end{array}$ & 1 & 1 & 2 & 4 & 11 \\
\hline $\begin{array}{l}\text { 25. I am able to critically review and interpret sources from } \\
\text { the target culture. }\end{array}$ & 2 & 2 & 3 & 7 & 20 \\
\hline $\begin{array}{l}\text { 26. I can connect language learning with acquiring } \\
\text { intercultural competences in my teaching practice. }\end{array}$ & 1 & 2 & 3 & 6 & 17 \\
\hline $\begin{array}{l}\text { 27. I can teach my students to relate between text and context } \\
\text { in the foreign language. }\end{array}$ & 0 & 1 & 2 & 3 & 8 \\
\hline $\begin{array}{l}\text { 28. I can teach my students to be critical of sources from the } \\
\text { target culture. }\end{array}$ & 0 & 1 & 2 & 3 & 8 \\
\hline
\end{tabular}

\section{Dialogue}

The purpose of interview items 29 to 33 is to explore English language teachers' information regarding dialogue, the third part of profession-oriented competence. These results are illustrated in Table 8.

Table 8

Participants' Responses Regarding Dialogue

\begin{tabular}{|c|c|c|c|c|c|}
\hline Frequency & B.A. & M.A. & Ph.D. & Sum & Percentage \\
\hline $\begin{array}{l}\text { 29. I can communicate in the target language in specific } \\
\text { situations with regard to the socio-cultural context } \\
\text { (formal/informal, appropriate, politeness, avoiding sensitive } \\
\text { subjects). }\end{array}$ & 2 & 1 & 3 & 6 & 17 \\
\hline $\begin{array}{l}\text { 30. I can analyze and solve problems that stem from } \\
\text { intercultural miscommunication. }\end{array}$ & 1 & 2 & 2 & 5 & 14 \\
\hline $\begin{array}{l}\text { 31. I can show students and let them experience, the } \\
\text { similarities and differences between their own culture and the } \\
\text { target culture. }\end{array}$ & 1 & 2 & 3 & 6 & 17 \\
\hline $\begin{array}{l}\text { 32. I can problematize the difficulties of intercultural } \\
\text { communication ("culture bumps") for students. }\end{array}$ & 0 & 1 & 3 & 4 & 11 \\
\hline $\begin{array}{l}\text { 33. I can stimulate the dialogue on cultural aspects between } \\
\text { students and thus stimulate the creation of a "third culture". }\end{array}$ & 0 & 1 & 2 & 3 & 8 \\
\hline
\end{tabular}

Findings of the interviews regarding the theoretical aspects of dialogs. About $20 \%$ of the participants had the ability to communicate in the target language in specific situations with regard to the socio-cultural context (Item 29). 15\% of the interviewees stated that they could analyze and solve problems stemmingfrom intercultural miscommunication (Item30).

Findings of the interview regarding the practical aspects of dialogs. In the next interview item (Item 31), when the teachers were asked whether they had the ability to represent the similarities and differences 
between their own culture and the target culture, about $17 \%$ of the teachers stated that they made use of a variety of teaching activities such as role play, brainstorming, discussion, and cross-cultural scenarios in order to show the differences and difficulties between their own culture and the target culture.

About $10 \%$ of the participants had the ability to problematize the difficulties of intercultural communication for the students by using culture bump activities. The majority of teachers asserted that they were familiar with the culture bump activities in the universities but they could not apply them in the class because of time limitation. And finally, with regard to item 33, about $8 \%$ of teachers could stimulate the dialogue on cultural aspects between students and thus stimulate the creation of a "third culture".

\section{Discussion}

With reference to the items included in the interview, 35 teachers with different educational degree expressed their opinion about different sections of the interview guide. The findings of the study can be compared and discussed from different aspects: comparing the theoretical and practical aspects of each competence of ICC, explaining each competence in light of the educational level of the participants in the study, comparing general competencies and profession-oriented competencies of the participants, evaluating the result with regard to four ecosystems of Bronfenbrenner's (1993) model, and finally analyzing the results based on the genotypic approach framework.

\section{Comparing the Theoretical and Practical Aspects of Each Competence of ICC}

The results indicated that Iranian English language teachers were not only aware of the knowledge about social groups and their cultures in one's own country, but also they were aware of their knowledge of the interlocutor's country. Additionally, this finding implied that the majority of Iranian English language teachers were aware of intercultural competence and its importance in English language learning. In general, the results regarding the theoretical aspects of each competence did not demonstrate any considerable difference among the participants. However, the frequency of practical aspects of competences in English language classes was found to be lower compared to the theoretical aspect. This might have been caused by the limitations English language teachers normally face when teaching culture. For example, some were concerned about the limitation of the time allocated for teaching culture in the classroom. Some referred to the fact that there was no appreciation for teaching culture in English language institutes in Iran. Similarly, there was no point for teaching culture in the observation checklists in the institutes. In addition, some participants stated that they felt the content materials or textbooks were shallow and superficial; there was little place for intercultural awareness in textbooks for learning English in Iran. The reasons behind this inefficiency might be stated as too much emphasis on grammar with the focal attention on British or American culture and the lack of adequate information regarding various cultures. Moreover, some of the participants maintained that the accessibility to local materials for improving ICC and cultural awareness was difficult. Furthermore, some interviewees mentioned that they were not free to choose their own teaching materials. Hence, beside the fact that teachers were aware of the importance of intercultural awareness institutes limited them to choose appropriate materials for teaching intercultural competence. To sum up, it can be inferred from the interviews that teachers seem weak in the practical aspects of each competence due to the conditions and regulations of institutes, time limitation, lack of effective materials, and freedom in choosing materials in order to promote ICC. 


\section{Explaining Each Competence in Light of the Educational Level of the Participants}

Another important finding is the significant difference between the groups of B.A. teachers, M.A. teachers, and Ph.D. candidates, with the B.A. group emphasizing the US culture more considerably than the other cultures. It is possible that the M.A. teachers and Ph.D. candidates have developed a deeper and more critical understanding of the role of culture of other countries than the B.A. group. One more outcome of this study was that M.A. and Ph.D. teachers had more ability to put their intercultural awareness into the practice in the class, possibly due to their more likely exposure to an intercultural discourse in their university courses.

\section{The Comparison Between General Competencies and Profession-Oriented Competencies}

Results of the present study also revealed that Iranian English language teachers appeared to show greater general competencies of openness, knowledge, and flexibility compared to profession-oriented competencies which were perspective, context, and dialogue. This can be explained via ecological exploration of teaching and learning culture in the context of Iran.

In Iran, parents and pupils are completely aware of the need to learn English language. Nevertheless, communication between Iranians and other societies, especially western societies, are somehow virtual. That is, their communication in English language is mainly built upon virtual communication media. Besides, the course books used in the Iranian English language institutes mainly encompass the American culture. Therefore, people' perceptions and attitudes regarding the foreign cultures might be limited to American culture overshadowing the need for communication with all the cultures in English. Hence, they might have some weakness in thinking and acting from different perspectives, the first part of profession-oriented competences; thus, they have less ability in the application of different cultural perspectives in their teaching practice.

In addition, regarding the context of Iran, people's few chances of communication with people from societies in their day-to-day conversations, which are mainly limited to virtual media might explain the limited preferences of English language teachers in realizing the needs of their learners in ICC and analyzing and solving the problems stemming from miscommunication which is rooted in not considering the sociocultural contexts while learning English. As a result, teachers may have inadequate knowledge about the basics and problems of intercultural communication and the ability to implement this knowledge in their teaching practice.

\section{Analyzing the Results Based on Bronfenbrenner's (1993) Model}

Using Bronfenbrenner's ecosystems framework, the researchers in this study tried to provide a fuller and contextualized understanding of the culture of English as an additional language among Iranian English language teachers. As mentioned in the review of literature, the context of education can be considered as a set of ecosystems, each one nested inside the next (Bronfenbrenner, 1979, 1993). According to Bronfenbrenner (1993), these ecosystems include: micro-, meso-, exo-, and macrosystems. The microsystem exists as the innermost layer, and includes activities, roles, and interpersonal relations experienced by the developing person in a direct interaction. The mesosystem embraces the linkages between two or more settings paving for the developing person. The exosystem involves the interconnection between two or more settings that indirectly influence process within the immediate setting. The macrosystem encompasses the overarching educational and sociocultural factors influencing other ecosystems. In the section below, findings are analyzed regarding the four levels of Bronfenbrenner's model.

Microsystem level. At the microsystem level, classroom environment and teachers' attitude, knowledge, and skills of ICC are two important factors interacting to produce the intercultural development. The interview 
with the participants revealed that teachers were aware of the knowledge about social groups and their cultures in one's own country and interlocutor's country. Most of them agreed with the importance of intercultural competence in language learning. However, they seemed to be less trained concerning the practical aspects of competences compared to the theoretical aspects. Besides, they allocated little time for improving ICC in the classroom. Instead, they preferred to put too much emphasis on the linguistic elements of language rather than cultural elements. In addition, they focused mainly on the American and British culture in order to improve cultural awareness of their learners.

Mesosystem level. The linkage at this level could be found in interconnection between the classroom and institute. Some potential aspects in mesosystem level include English language institutes policies for evaluating teachers, i.e., observation checklists checking teachers' behavior, and the teachers' experience and activities outside the classroom shaping the culture of teaching English. Some of the interviewees alleged that they could not be completely free to choose their own teaching materials. Some mentioned the fact that there was no acknowledgment for teaching culture in the institutes and also there was no point for teaching culture in the observation checklists in the institutes. This potential gap between teachers' attitudes and knowledge of ICC on the one hand and the institute policies and criteria evaluation of teachers' behavior in the classroom on the other hand may lead to Iranian English language teachers' unwillingness to improve themselves in profession-oriented competences and practical aspects of ICC.

Exosystem level. The link between English language institutes and universities can be discussed at this level. This includes the universities curriculum and plans for promoting teachers' knowledge, attitude, and skills of ICC on one hand, and institute curriculum designs and the role of ICC in the policies of the institutes on other hand. Due to the development of higher education in Iran, there are more chances for master's degree and Ph.D. education in the field of applied linguistics than before. This sets the stage for more exposure of Iranian English language teachers to an intercultural discourse in universities courses. Additionally, student teachers have more access to academic articles; thus, they are familiar with the latest models of ICC. However, results showed that the intercultural awareness stayed at the theoretical knowledge and had not been yet applied in a practical form. For instance, participants stated that the role of ICC in the curriculum of the institutes was neglected. They also felt the content materials or textbooks were shallow and superficial regarding the practical aspects of ICC. The reasons behind this might pivot upon the substantial gap between what teachers study and learn at the academic context, i.e., universities and practical context, i.e., institutes and schools of English language teaching in the training and promoting ICC.

Macrosystem level. The form of interaction with other cultures and also the local culture of teaching English as an additional language and the linkage between social and educational factors can also be discussed at them macrosystem level. Due to the small number of tourists visiting Iran, Iranians' interactions with people from other cultural societies are limited to virtual channels via internet, media, and textbooks. Indeed, Iranian people could not communicate with other societies in day-to-day conversations. Therefore, they might night have sufficient knowledge in terms of thinking from different cultural perspectives or they might not consider sociocultural context while communicating in English, weakness in dialogue and creating the third place. Thus, learning English within this context, English language teachers in Iran may have inadequate knowledge about the basics and problems of intercultural communication and the ability to implement this knowledge in their teaching practice. These factors may explain the teachers' insufficiency in profession-oriented competencies of ICC. Such conditions might influence the local culture of teaching English as an international language in Iran. 
The gap between the knowledge of Iranian teachers in ICC mainly due to the academic development in Iran, and the practice of ICC, generally limited owing to the policies and regulations of the English language institutes emphasizing linguistic competence and native-like acquisition of English language may still add to the controversy of the implications and applications of ICC within the context of Iran at a macro level.

\section{Analyzing the Results Based on the Genotypic Approach Framework}

A sociocultural genetic-analytic perspective provides an explanatory framework to derive meaning from ecological exploration of teaching culture in Iran. By using the genetic-analytic spans, described earlier, Iranian English language teachers' attitudes, knowledge, and skills of teaching culture can be analyzed. These spans include:

Phylogenetic span: focuses on the development of language teachers as natural species and their physical evolution;

Cultural-historic span: a focus on the broader policy context within which Iranian teachers' activity is situated;

Ontogenetic span: a discussion of what Iranian teachers bring as the teaching cultural and intercultural competence (i.e., background, experience, and personal history) to the system;

Microgenetic span: Iranian teachers' engagement with their immediate sociocultural context in relation to teaching cultural and intercultural competence.

Ontogenetic development of teachers in teaching culture. As mentioned earlier, due to the development of higher education in Iran, more chances for master's degree and Ph.D. in applied linguistics exist than before. Furthermore, these students (language teachers of institutes) accessibility to academic research findings and familiarity with the latest models of ICC have raised their knowledge regarding the importance of teaching culture as an indispensible part of English language teaching. For instance, one of the Ph.D. candidates stated that:

In my opinion, language is just a part of culture. I mean, a shared language, allows people of different cultures to express themselves and communicate in a way so that everyone understands in the same way what they are talking about. And, so the culture is maintained through communication either in speech or in written form. (personal communication)

Cultural-historic analysis of teaching culture in Iran. As the interviews with the Iranian English language teachers revealed, a sharp contrast is observed between these teachers' attitudes towards teaching culture and their practice in the classroom which is rooted in the divergence between their ontogenetic development of culture teaching on one hand and the policies of the English language institutes developing within the cultural historic span on the other hand. The regulations of the English language institutes have disempowered teachers in terms of the practice of ICC irn Iran. They are mainly evaluated by how they improve the four skills of English language, how they improve the accuracy of their learners in pronunciation and grammar, and how much time they allocate to these skills. Despite ontogenetically being aware of the role of different aspect of ICC in the practice of English as an international language, they might be still oriented to focus on the expectation of the institutes in their practice.

\section{Conclusion}

One of the reasons for investigating the culture of English as an additional language among English language teachers, specifically teaching intercultural competence, was to be able to provide teachers and 
researchers with the potential factors which might influence on their existing beliefs about teaching ICC. Applying Bronfenbrenner' $(1979,1993)$ nested ecosystems model as an analytic framework, the researchers in this study explored preliminary ecological conceptualization of ICC among Iranian English language teachers. This model demonstrates its utility in examining ICC not in a social vacuum but at a larger social structure. Based on the findings, it is postulated that Iranian English language teachers' attitudes, skills, and knowledge with regard to general intercultural competencies and profession-oriented intercultural competencies are socioculturally constructed as a function of the interaction of teachers and learners with environmental factors, both inside and outside the classroom. Such a perspective was clarified in light of Vygotsky's genotypic approach to discuss how teachers think, know, and behave as historical and sociological agents within larger contexts for practice, the English language institutes policies, and the ontogenetic development of Iranian English language teachers intertwine.

In turn, an ecological exploration in light of Vygotsky's genotypic framework of the culture of English as an additional language among English language teachers opens further possibilities for resolving the problematic gap between theory and practice which seems to be an ongoing concern for the field of applied linguistics (Freeman, 2007). It also offers a valuable starting point for analyzing current developments of ICC in a way that allows us to join and move forward to address new challenges about the theoretical and practical aspects of teaching of ICC.

\section{References}

Bennett, M. J. (2004). Becoming interculturally competent. In J. S. Wurzel (Ed.), Toward multiculturalism: A reader in multicultural education (pp. 62-77). Newton, MA: Intercultural Resource Corporation.

Bronfenbrenner, U. (1979). The ecology of human development. Cambridge, MA: Harvard University Press.

Bronfenbrenner, U. (1993). The ecology of cognitive development: Research models and fugitive findings. In R. H. Wozniak and K. W. Fischer (Eds.), Development in context: Acting and thinking in specific environments. The Jean Piaget symposium series (pp. 3-44). Hillsdale, NJ: Erlbaum.

Bronfenbrenner, U. (2009). The ecology of human development: Experiments by nature and design. London: Harvard University Press.

Byram, M. (1989). Cultural studies in foreign language education (Vol. 46). Clevedon, UK: Multilingual Matters.

Byram, M. (1997).Teaching and assessing intercultural communicative competence. Clevedon, UK: Multilingual Matters.

Byram, M., Gribkova, B., \& Starkey, H. (2002). Developing the intercultural dimension in language teaching: A practical introduction for teachers. Strasbourg: Council of Europe.

Corbett, J. (2003). An intercultural approach to English language teaching. Clevedon, Great Britain: Multilingual Matters.

Crozet, C., \& Liddicoat, A. J. (2000). Teaching culture as an integrated part of language: Implications for the aims, approaches and pedagogies of language teaching. In A. J. Liddicoat and C. Crozet (Eds), Teaching languages, teaching cultures (pp. 1-8), Melbourne: Language Australia Ltd..

Deardorff, D. (2008). Intercultural competence: A definition, model, and implications for study abroad. In Developing intercultural competence and transformation: Theory, research, and application in international education. Sterling, VA: Stylus.

Fang, T. (2012). Yin Yang: A new perspective on culture. Management and Organization Review, 8(1), 25-50.

Fantini, A. E. (2009). Assessing intercultural competence. In The SAGE handbook of intercultural competence (pp. 456-476). California: SAGE Publications, Inc..

Freeman, D. (2007). Research "fitting" practice: Firth and Wagner, classroom language teaching, and language teacher education. The Modern Language Journal, 91 (s1), 893-906.

Haugen, E. (1972). The ecology of language. Stanford, CA: Stanford University Press.

Holliday, A., Hyde, M., \& Kullman, J. (2010). Intercultural communication: An advanced resource book for students. NY: Routledge.

Hu, A., \& Byram, M. (2009). Intercultural competence and foreign language learning: Models, empiricism, assessment. Tübingen, Germany: Narr. 
Kalsbeek, A. van. (2006). Culturencontrasteren: eenzinvolletaak? (Cultures contrast: Meaningful work?). In P. Hiligsmann, L. Beheydt, L. Degand, P. Godin, and S. Vanderlinden (Eds), Neerlandistiek in Frankrijk en in FranstaligBelgië/Lesétudesnéerlandaises en France et en Belgique francophone (Dutch studies in France and in French-speaking Belgium) (pp. 397-413). Hilversum: Presses UCL.

Kramsch, C. (1993). Context and culture in language teaching. Oxford: Oxford University Press.

Kramsch, C., \& Steffensen, S. V. (2008). Ecological perspectives on second language acquisition and socialization. In Encyclopedia of language and education (pp. 2595-2606). US: Springer.

Van Leir, L. (2004). The ecology and semiotics of language learning: A sociocultural perspective. Boston: Kluwer Academic. Vygotsky, L. S. (1980). Mind in society: The development of higher psychological processes. London: Harvard university press. $\mathrm{Xu}$, Z. (2013). Globalization, culture and ELT materials: A focus on China. Multilingual Education, 3(1), 1-19.

Zarate, G., Lévy, D., \& Kramsch, C. J. (2008). Précis du plurilinguismeet du pluriculturalisme (The precise plurilinguist meets pluriculturalism). Paris: Éditions des archives contemporaines. 